\title{
SIX NEW LIVING SPECIES OF MURICACEAN GASTROPODS
}

\author{
William K. Emerson \\ American Museum of Natural History \\ New York, N. Y. 10024
}

\author{
Anthony D'Attilio
}

and

Natural History Museum

San Diego, California 90112

\begin{abstract}
The following new species of gastropods referable to the Muricidae are described: Pteropurpura benderskyi from West Africa; Favartia guamensis and $\mathrm{F}$. dorothyae from the western Pacific, and F. elatensis from the Red Sea; Murexiella mactanensis from the western Pacific; and Siphonochelus radwini from the western Atlantic. A recently described species, Murexiella martini Shikama, 1977, from the western Pacific, is illustrated and a supplementary description is given. Dermomurex neglecta (Habe and Kosuge, 1971), from the western Pacific, is illustrated and a translation of the original description is provided.
\end{abstract}

At the time George E. Radwin and the junior author were preparing the text for "Murex Shells of the World, An Illustrated Guide to the Muricidae" (Radwin and D'Attilio, 1976), a number of taxa were recognized by them as new species. Fifteen of these species were described in an appendix to their book. Although they intended to describe elsewhere several other taxa that were received after the text of the book was completed in mid-1971, the tragic and untimely death of Dr. Radwin in 1977 terminated their joint venture.

At the request of the junior author, the senior author has joined him in the preparation of the present report, which was based in part on preliminary notes prepared jointly by D'Attilio and Radwin for two of the taxa described herein. The new taxa are classified largely according to the system followed by Radwin and D'Attilio (1976).

\section{ACKNOWLEDGMENTS}

We are grateful to the following collectors for the loan and/or donation of specimens: Israel Bendersky, L. J. Bibbey, Albert E. Deynzer, Francis Fernandez, Dorothy and Robert Janowsky, Leo Kempczenski, Don Pisor, and Eugenia Wright. Dr. Joseph Rosewater of the Department of Invertebrate Zoology, National Museum of Natural History, Smithsonian Institution and Dr. H. K. Mienis of the Zoological Museum, Hebrew University of Jerusalem lent additional material. Dr. Emily H. Vokes of the Department of Geology, Tulane University, provided data and the photographs used to illustrate figures 17 and 18. Masao Tabakotani of Bronxville, New York, generously contributed a translation of Japanese text. William E. Old, Jr. and G. Robert Adlington of the American Museum of Natural History kindly provided respectively, technical assistance and the photography.

\section{INSTITUTIONAL ABBREVIATIONS:}

$\mathrm{AMNH}=$ American Museum of Natural History, New York, New York

HUJ = Zoological Museum, Hebrew University of Jerusalem, Israel

$\mathrm{NMNH}=$ National Museum of Natural History, Washington, D.C.

SDMNH $=$ San Diego Museum of Natural History, San Diego, California

\section{FAMILY Muricidae \\ SubFAmILY Muricinae}

Genus Dermomurex Monterosato, 1890

Type species: Murex scalarinus Bivona-Bernardi, 1832 (= M. scalaroides Blainville, 1829), by original designation.

Dermomurex neglecta (Habe and Kosuge, 1971) Figs. 17, 18

"Description: Shell distinguished by its varices, five in number, in each whorl. They are broad and somewhat prosocline at the shoulder to 
suture position. Whorls between varices are sculptured by numerous fine spiral striae so that it looks almost smooth. Siphonal fasciole is outstanding and umbilicus is open. Shell white with slight yellowish tinge in color."

"This species is distinguished for the shape and varices. Actually two specimens are known, both caught in South China Sea and brought back to the port of Kaohsiung, Taiwan." (Translation of the Japanese text, courtesy of M. Tabakotani.)

Measurements: Holotype, length $22.5 \mathrm{~mm}$, width $11.2 \mathrm{~mm}$; specimen illustrated herein, length $20 \mathrm{~mm}$, width $11.00 \mathrm{~mm}$. (Wright collection).

Type locality: "South China Sea", fide Habe and Kosuge (1971, page 7). Here restricted to off Bohol Island, Philippines.

Material examined: 1 specimen, off Balicason, Bohol Island, Philippines, in 366 meters, Eugenia Wright collection.

Remarks: At the suggestion of Dr. Emily H. Vokes, we have presented here a translation of the description of this poorly known western Pacific taxon, together with photographs of a specimen from the Philippines (figures 17, 18), which along with another one, had been sent to her for identification. Although this species was originally described as Phyllocoma neglecta by Habe and Kosuge (1971, p. 7, text figure), it is referable to the genus Dermomurex and is the first Recent record of the genus (sensu stricto) in the Indo-Pacific. Vokes (1975, p. 129) cited this record based on the Philippine specimens which were thought to represent an undescribed species. She pointed out $(1975$, op. cit.) that the specimens lack apertural denticulations on the outer lip, in contrast to the previously known representatives of Dermomurex (sensu stricto). According to Dr. Vokes (in litt.) the present species is a probable descendent of Dermomurex acuticostatus (Wanner and Hahn, 1935, p. 254, pl. 19, figs. 8-10) from the Miocene of Java.

\section{SuBFAmILY Ocenebrinae}

Genus Pteropurpura Jousseaume, 1880

Type species: Murex macropterus Deshayes, 1839 , by original designation.

\section{Pteropurpura benderskyi, n. sp.}

Figs. 1, 2, 19

Description: Shell small for genus, attaining 23 $\mathrm{mm}$. in length, trigonally fusiform in appearance. Spire acute and high, with $1^{1 / 2}$ polished, brown nuclear whorls, followed by 5 convex, postnuclear whorls; suture distinct, not strongly impressed. Body whorl moderate in size. Aperture ovate, with peristome entire and mostly erect, except for the posterior portion of left side in the parietal region. Siphonal canal broad, sealed (except at the recurved, tapering distal end), moderate in length and accommodating the siphonal fasciole. Body whorl with three winged varices; each varix with webbing between prominent spine-points. A medial costate ridge and two less prominent flanking costae intervene between each pair of consecutive varices. Spiral sculpture of numerous primary and secondary cords extending over body and siphonal canal. Primary cords strongest on dorsal surfaces of the spines. Spine at shoulder margin longest; body with a less prominent spine medially placed and with a minor spine at the base of body whorl and on the upper portion of siphonal canal. Leading, or ventral sides, of varical spines weakly open; last varix with leading edge sculptured with fine, low undulating lamellae and with some growth lines raised at intervals to give a somewhat scabrous texture to the surface. Shell tan to dark-brown, paler on the varical surfaces; aperture off-white and porcelaneous. Operculum: The morphology is typically ocenebrinean, as described by Radwin and D'Attilio (1976, p. 111).

Radula: Radular dentition is similar in morphological characters to those of the type species of Pteropurpura, P. macroptera (Deshayes, 1839); consult the radular illustrations of the Deshayes' taxon (Radwin and D'Attilio, 1976, p. 131, fig. 81) with the basal and frontal views of a rachidian and a frontal view of a lateral tooth of the present species (figure 19 herein).

Measurements: Holotype, length $23 \mathrm{~mm}$, width, including varices $13.9 \mathrm{~mm}$; smallest paratype (SD MNH no. 72626), $17.7 \mathrm{~mm}$ in length.

\footnotetext{
FIGS. 1 and 2, Pteropurpura benderskyi n. sp., holotype, AMNH 183819, X3. 3 and 4, Favartia dorothyae n. sp., holotype, AMNH 183821, X3. 5 and 6, Favartia rosea Habe, 1961, Janowsky collection, trawled in Kii Channel, Wakayama Prefecture, Japan, in 146 meters, $\times$ 3. 7 and 8, Favartia mactanensis n. sp., holotype, AMNH 187186, Xs. 9 and 10, Murexiella martini Shikama, 1977, SDMNH 72627, Bohol Island, Philippines, $\times 2$ (Stated enlargements are an approximation)
} 

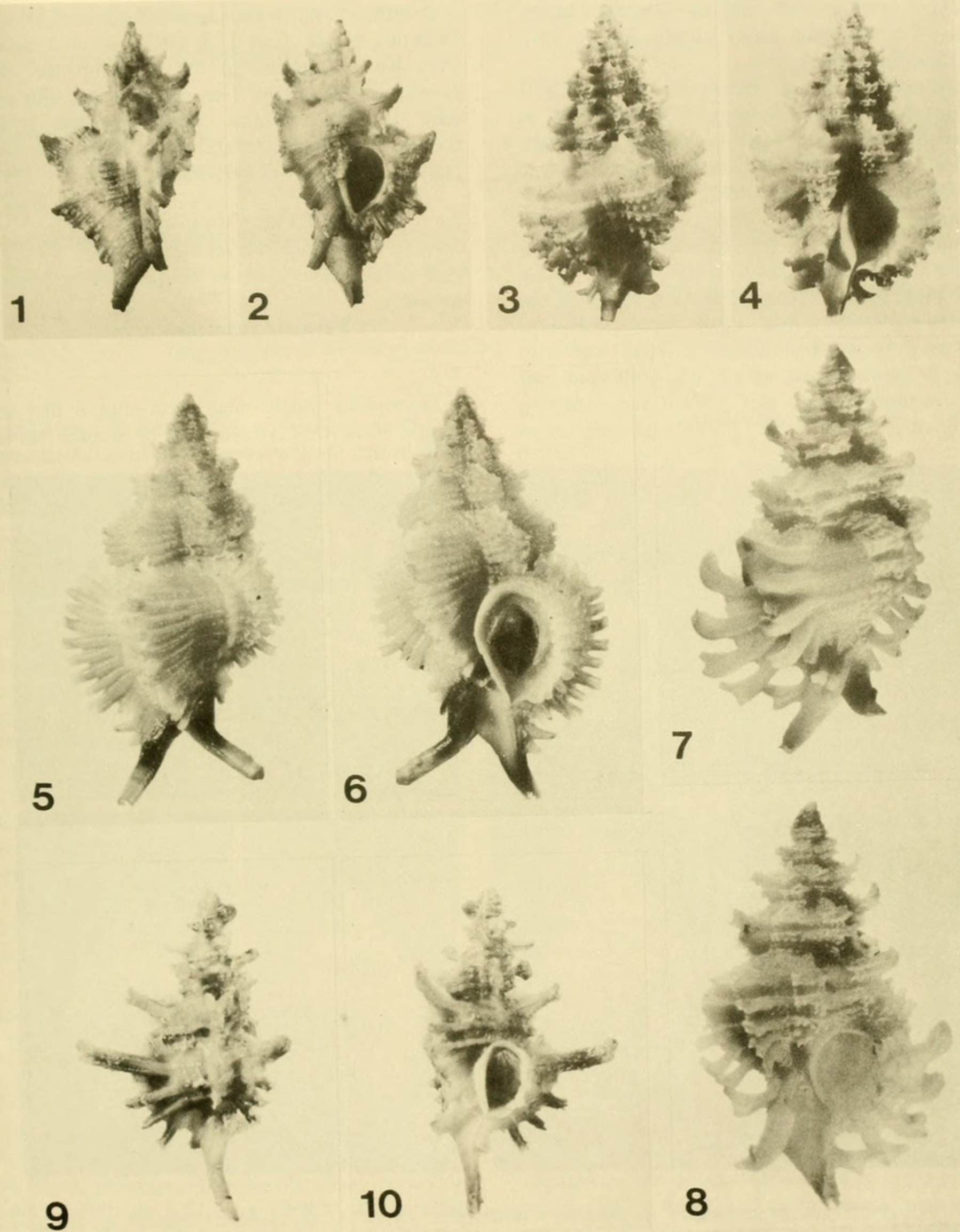
Type locality: Off Luanda, Angola, Africa, dredged in 50 meters, sandy bottom, July 15, 1977, Francis Fernandez collector.

Material examined: Holotype AMNH 183819, from type locality, 1 paratype SDMNH 72626, ex Bendersky collection, and 1 paratype, Janowsky collection, both from off Luanda, Angola, dredged in 80 meters, February 10, 1977.

Remarks: Until the discovery of this new species, only one living representative of this genus was known to occur in the Atlantic Ocean. The other living Pteropurpura are found in the northern Pacific, with three in northwestern waters (largely off southeastern Japan) and with five in northeastern waters off California and northwestern Mexico (see Radwin and D'Attilio, 1976 , pp. 129 to 133). The present species (figures
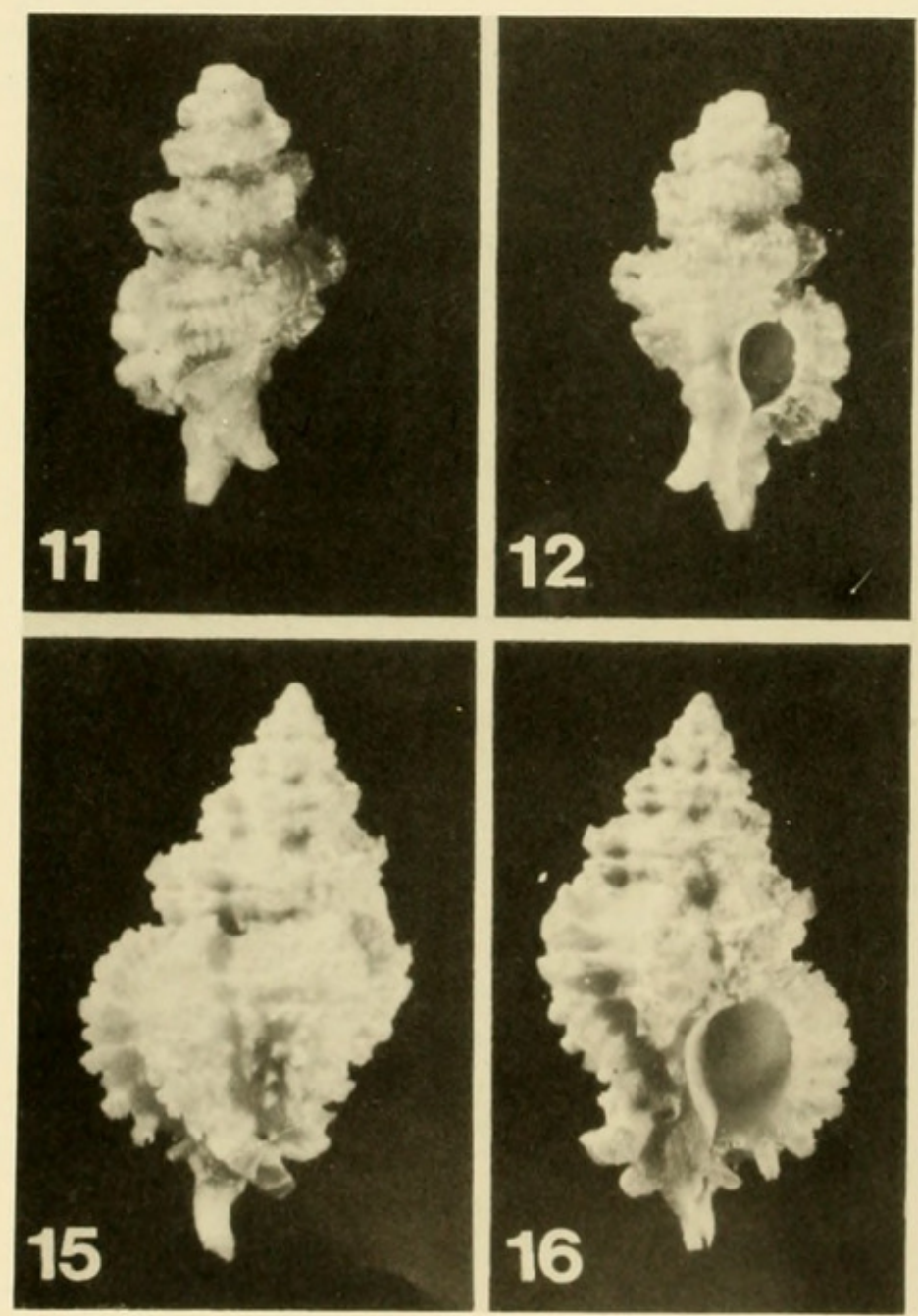

1, 2) differs from $P$. bequaerti (Clench and Pérez Farfante, pl. 21, figs. 1, 2, 1945), which ranges from North Carolina to the Dry Tortugas, in several characteristics (see comparative data in table 1). The two taxa clearly represent twin species, or cognates, separated by the present expanse of deep water of the Atlantic Basin.

\section{SubFAmILy Muricopsinae}

Genus Favartia Jousseaume, 1880

Type species: Murex breviculus Sowerby, 1834, by original designation.

\section{Favartia guamensis n. sp.}

Figs. 11, 12

Description: Shell small, attaining $8 \mathrm{~mm}$ in length, fusiform. Characterized by strong rugose
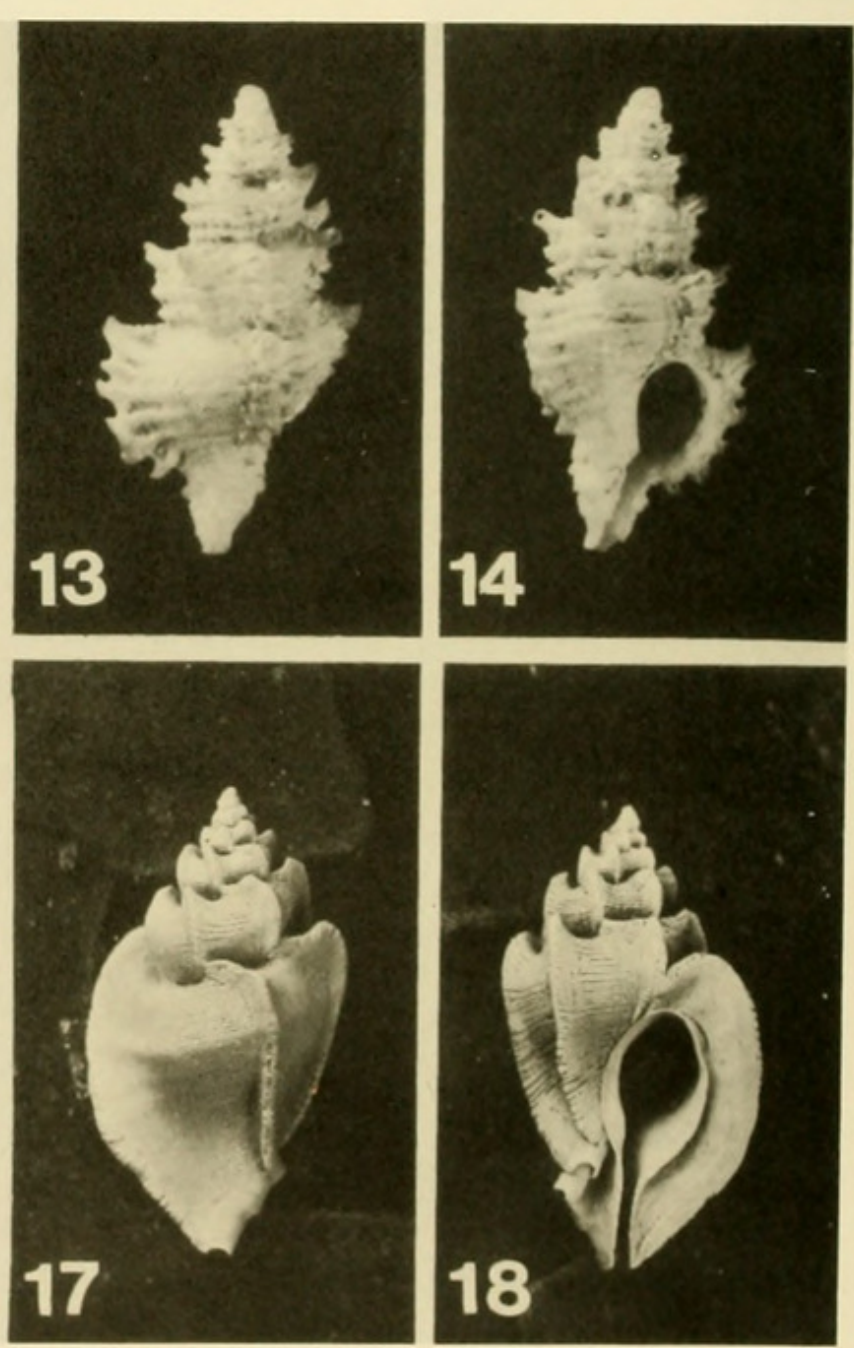

FIGS. 11 and 12, Favartia guamensis n. sp., holotype, SDMNH 72625, $\times 5.13$ and 14, Favartia elatensis n. sp., paratype, SDMNH 63254a, $\times 5.15$ and 16, Favartia dorothyae n. sp., paratype, AMNH 183822, $\times 3.17$ and 18, Dermomurex neglecta (Habe and Kosuge, 1971); Wright collection, off Bohol Island, Philippines, X2. (Stated enlargements are an approximation) 
TABLE 1. Comparative diagnostic characters of Pteropurpura bequaerti and Pt. benderskyi

Pteropurpura bequaerti

$\begin{array}{ll}\text { Maximum size } & 42 \mathrm{~mm} \\ \text { Numbers of whorls } & 6 \text { to } 7 \\ \text { Outer lip } & \text { crenulated } \\ \text { Varices } & \text { blade-like } \\ \text { Axial sculpture } & \text { a single, low knob } \\ \text { Spiral sculpture } & \begin{array}{l}\text { terminates in toothlike points on varical } \\ \text { margins }\end{array}\end{array}$

Color gray-white; tip of siphonal canal suffused with purple-brown.
Pt. benderskyi, n. sp.

$23 \mathrm{~mm}$

5 (or more?)

not noticeably crenulated

spine-like projections

medial costae and 2 less prominent flanking costae.

varical margins extended into 4 broad-based, spiny terminations, with scabrous lamellae on ventral surface.

$\tan$ to dark-brown, paler on ventral surface sculpture. Protoconch low, smooth with $1 \frac{1}{2}$ whorls; followed by 5 convex whorls; suture deep but obscured at varices; spire well elevated. Aperture ovate; peristome weakly erect; anal sulcus deep, constricted in front into a closed channel. Siphonal canal with rostrate fasciole, broader above, tapering distally, slightly recurved with a narrow sinuous opening. Shell with 5 strong, spiral cords, squarish in cross-section and with an additional cord on the canal; cords crossed by strongly elevated fimbriae; fimbriations extend into the interspaces. Spiral cords with a strong central groove, crossed by fine lines, and with fimbriae forming strong, canopylike scales; scales further interrupted axially by 5 to 8 fine grooves; scales scalloped on terminal edge. Varical flanges elevated and terminally wavy; early whorls with 6 varices; body whorl with 4 varices. Color of shell deep orange-red, ranging to yellow in the four specimens examined.

Measurements: Holotype, $7.5 \mathrm{~mm}$ in length; largest paratype, $7.7 \mathrm{~mm}$ in length; smallest paratype, $6.6 \mathrm{~mm}$ (Pisor collection).

Type locality: Off Orote Cliffs, Guam, Marianas Islands, in 18 to 21 meters under large boulders, 5-1-1977, Leo Kempczenski collector.

Material examined: Holotype, SDMNH no. 72625; 1 paratype, Leo Kempczenski collection and 1 paratype, AMNH no. 183820, all collected by Leo Kempczenski from type locality; 1 paratype from type locality, Don Pisor collection;
1 paratype from coral rubble, in 18 meters, SCUBA diving, 1977, A. Deynzer collection.

Remarks: The small size of the present species (figures 11, 12), complemented by the development of elaborate sculpture, the elongated body, and the rich coloring serve to distinguish this taxon from any of its congeners.

\section{Favartia dorothyae, n. sp.}

Figs. 3, 4, 15, 16

Description: Shell small for genus, attaining 9 $\mathrm{mm}$ in length, broadly fusiform; spire elevated but small in proportion to body whorl; protoconch of $1 \frac{1}{2}$ whorls; post-nuclear whorls 6 in number; suture distinct. Body whorl obese, with a small ovate aperture; anal sulcus weaklydeveloped. Lower half of inner lip erect, adherent above; outer lip crenulated and sculptured within by 7 long lirae. Anterior end of columella ornamented by a small tooth. Siphonal canal broad above, tapering and distally recurved; siphonal fasciole rostrate. Body whorl with 5 major cords and with one major cord on canal; each cord subdivided by 4 or 5 incised lines. Three secondary cords situated above the major cord at shoulder. A secondary cord present on the body whorl below the second and third cords. A major cord appears on the canal with secondary cords above and below it. Additional minor spiral cords present on the body as well as over the shoulder. Five varices form the axial sculpture. Starting at 
each varical margin, the cords ascend to the strongly developed varix where they terminate and are recurved distally. The leading side of each varix bears 7 or 8 fimbriae which develop into scaly sculpture over the whorls. The shell color ranging from warm-white to carmine with the early whorls golden-hued; characteristically with the columella, the dorsal and ventral sides of the canal, and the base of the body whorl are all strongly colored a rosy pink.

Measurements: Holotype $15.9 \mathrm{~mm}$ in length, width $9.6 \mathrm{~mm}$; smallest paratype (lacking a mature siphonal canal) $13.7 \mathrm{~mm}$ (AMNH 183822); largest paratype, $16.2 \mathrm{~mm}$ (SDMNH no. 72624).

Type locality: Off Punta Engaño, Mactan Island, Philippines, in about 30 meters, (obtained in tangle or gill nets), 1977, ex Dorothy and Robert Janowsky collection.

Material examined: Holotype AMNH 183821 (figures 3, 4), and three paratypes AMNH 183822, 1 paratype SDMNH 72624 (figures 15, 16, AMNH 183822a); 3 paratypes, Janowsky collection; 1 paratype Leo Kempczenski collection; all from the type locality. Three specimens, Panglao, Bohol Island, Philippines, in trap, 1977-1978, A. Deynzer collection.

Remarks: This species (figures $3,4,15,16$ ) with its distinct apertural coloration and delicate frostlike sculpture may be easily distinguished from the following congeners: $F$. marjorae (Melvill and Standen, 1903), to which it bears some resemblance, by comparison with a photograph of the holotype in Radwin and D'Attilio, 1976 , fig. 95 , p. 150 . F. marjorae, which has a less swollen body and a higher spire, is grey in color and occurs in the Persian Gulf. $F$. balteata (Sowerby, 1841) from the western Pacific has a more strongly sculptured shell, with welldeveloped black squarrose varices, and has a brown shell with a red aperture. $F$. salmonea (Melvill and Standen, 1899) has a comparatively higher spire, possesses a decided gap between the body cords and those on the canal, and is pale reddish orange, darkest at the varices. It has not been reported from the northern area of the western Pacific. F. rosea Habe, 1961, (herein illustrated, figures 5, 6), from southeastern Japan, has a larger (23 $\mathrm{mm})$, fleshy orange to yellow col- ored shell, with the varical areas conspicuously more rounded (swollen), and the surface not noticeably scabrous.

\section{Favartia elatensis n. sp.}

Figs. 13, 14

Description: Shell small for genus, attaining 8 $\mathrm{mm}$ in length, fusiform; spire high; protoconch $1 \frac{1}{2}$ rounded whorls, followed by 5 post-nuclear whorls; suture distinct. Aperture ovate, outer lip strongly undulate reflecting the dorsal sculpture; inner lip adherent; anal sulcus broad and simple; canal moderately long, narrowly open, tapering, weakly recurved, siphonal fasciole moderately developed. Axial sculpture strong with growth lines developing into widely spaced lamellae; vaulted scales formed by expansion of lamellae over the spiral cords. Six varices on post-nuclear whorls of spire; four on body whorl. Varices crossing at shoulder diagonally onto contiguous whorl. Spiral sculpture of 6 squarish and knobby cords on body whorl, with one cord, on the canal; cords grooved spirally, but dividing somewhat irregularly into unequal widths, to form unequal scaly ornamentation. Cords at the varical margins expanded into lobes; final varix with a recurved margin. Varical areas of shoulder extending into lobes with vaulted edge on leading side. Shell color uniformly fleshy white.

Measurements: Holotype $7.8 \mathrm{~mm}$ in length, 3.9 $\mathrm{mm}$ in width; largest paratype, $7.9 \mathrm{~mm}$ in length (SDMNH no. 63254a, figures 14, 15); smallest paratype (immature) $4.2 \mathrm{~mm}$ (HUJ no. 10.202/8).

Type locality: Elat, Gulf of Elat, Israel, $29^{\circ} 32^{\prime}-29^{\circ} 31^{\prime} \quad$ N., $36^{\circ} 58^{\prime}-36^{\circ} 59^{\prime}$ E., in 190 meters from grab sample, October 8, 1965.

Material examined: Holotype and 7 paratypes HUJ 10.202/8 from the type locality; 2 paratypes SDMNH 63254, ex HUJ 10.202/RS-18, Elat, Gulf of Elat, $29^{\circ} 32^{\prime}-29^{\circ} 31^{\prime} \quad$ N., $36^{\circ} 58^{\prime}-36^{\circ} 59^{\prime}$ E., in 190 meters; 1 paratype AMNH 183823, ex HUJ $10.204 / 1$, Elat, Gulf of Elat, $29^{\circ} 31^{\prime}-29^{\circ} 32^{\prime}$ N., $34^{\circ} 58^{\prime}-36^{\circ} 59^{\prime}$ E., in 250 meters, October 8,$1965 ; 8$ paratypes, HUJ 10.203/9 Elat, Gulf of Elat, $29^{\circ} 31^{\prime}-29^{\circ} 32^{\prime}$ N., $34^{\circ} 58^{\prime}-34^{\circ} 59^{\prime}$ E., in 80 meters.

Remarks: The presence of squarely-formed spiral cords terminating in lobed projections, and the relatively small size of the shell (figures 13 , 
14) serve to distinguish this species from others in the genus. This species is presently known only from the Gulf of Elat. Although Recent Favartia are not recorded in the Mediterranean, some Indo-Pacific species with shells larger than that of $F$. elatensis occur intertidally or in shallow depths elsewhere in the Red Sea.

Genus Murexiella Clench and Farfante, 1945

Type species: Murex hidalgoi Crosse, 1869, by original designation.

\section{Murexiella mactanensis n. sp.}

Figs. 7,8

Description: Shell medium-sized for genus, attaining $22 \mathrm{~mm}$ in length; biconically fusiform; spire elevated, with 5 convex whorls; protoconch dense white and with suture impressed. Aperture broadly ovate; peristome erect, more weakly elevated on the left posterior side; margin of outer apertural lip wavy, with the 5 undulations reflecting the presence of the external cords; anal sulcus weak; siphonal canal moderately long, narrowly open; tapering tube-like and strongly recurved; siphonal fasciole strong, spaced some distance from body sculpture. Axial sculpture of 5 erect varices terminating distally as open spines of moderate height; final varix set-back from aperture, bent back and with the leading side richly scabrous; scabrous lamellae on leading side of all varices to the margin of each varix; intervarical area with weaker lamellae or with lamellae developing into scales. Spire with 6 varices, the varices more weakly erect crossing the shoulder diagonally and continuing on to the varix of preceeding whorl. Body whorl with 5 spiral cords; cords nearly erect on varices and terminate as upturned spines. Spines at shoulder longest; the first two paired, followed by the remaining 3 ; spines open, marginally not ornamented and on the final varix broadest distally with the edges recurved on the leading side; spines subdivided lengthwise by incised lines into 2 or 3 unequal areas. Minor cords situated between large ones, with a gap between the last cord on the body and the spinal cord on the canal. Shoulders ornamented, notably on the final varix, with a short lobe having 3 or 4 pointed spines.
Shell color: on the holotype, the spire, intervarical areas, and fasciole flesh-pink, darkest towards the apex; varical areas white, especially terminally; aperture white. In the paratypes, the amount of the flesh-pink coloration varies in intensity and location on the shells.

Measurements: Holotype $21.7 \mathrm{~mm}$ in length, width (including spines) $14.3 \mathrm{~mm}$; smallest specimen (4 post-nuclear whorls; Pisor collection), length $12.9 \mathrm{~mm}$.

Type locality: Off Punta Engaño, Mactan Island, Philippines, in about 30 meters (obtained in tangle or gill nets), 1977, ex Dorothy and Robert Janowsky collection.

Material examined: Holotype AMNH no. 187186 (figures 7, 8); 1 paratype Panglao, Bohol Island, Philippines, in about 180 meters, 1977, Albert Deynzer collection; 1 paratype SDMNH 73800 (ex Pisor collection) and 1 paratype Don Pisor collection, both Bohol Straits, Philippines, in about 50 meters.

Remarks: The present species, characterized by having the 5 varices terminating in simple, unornamented spines, may be assigned to Murexiella (sensu stricto), based on the typological genusgroup concept of Murexiella Clench and Pérez Farfante, 1945 (see Radwin and D'Attilio, 1976, p. 155-161). Several western Pacific species were assigned by Ponder (1972) to Murexiella, which he regarded as a subgenus of Favartia. These other taxa differ from the new species by their closer relationship to Favartia (sensu stricto). Comparison can be made with the Indo-Pacific species F. salmonea (Melvill and Standen, 1899) and $F$. voorwindei Ponder, 1972 , in which the body whorl and sculpture are somewhat similar. They lack, however, well-developed spines with connecting webbing, characters that serve to distinguish taxa referable to Murexiella (sensu stricto). This new species, together with the one following, brings to two the number of distinctive Murexiella recognized recently in the central Philippines.

Murexiella martini Shikama, 1977

Figs. 9,10

Supplemental description: A slender fusiform shell, attaining $28 \mathrm{~mm}$ in height (holotype); spire 

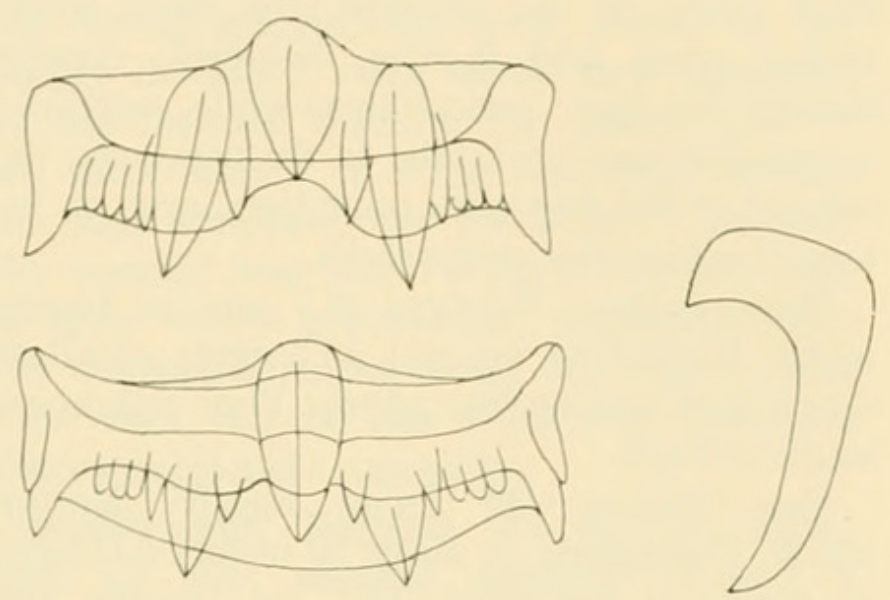

19

FIG. 19. Pteropurpura benderskyi $n . s p$., radular dentition (drawings by Anthony D'Attilio); greatly enlarged.

well-elevated, with a protoconch of $1 \frac{1}{4}$ whorls, followed by 6 post-nuclear whorls; body whorl large, strongly spined at shoulder; suture impressed. Aperture ovate, peristome entire and strongly elevated; sulcus shallow and broad; outer lip with 4 extended, lobe-like crenulations reflecting the dorsal spiral sculpture. Siphonal canal narrowly open, broad above, strongly recurved, tapering axially and tube-like distally, with fasciole formed by terminations of the two previous canals. Body whorl with 3 spinose varices; varical margins thick, erect and continuing nearly midway to the intervarical area; basal varix crossing the shoulder diagonally and extending to the previous whorl. Four strong spiral cords, one at shoulder separated by a gap from the group of 3 below; cords terminating in long moderately open spines at the varices; spine at the shoulder longest, those below about $1 / 2$ as long; cords subdivided by 3 to 5 incised lines. Spines connected by a flangelike web ornamented with a scabrous lamellate surface on the leading side; varical webbing with one small, medial cord and with a weakly defined cord on either side of the central cord. Scaly lamellae on entire surface of the shell, exclusive of the canal, and with most prominent lamellar development on the raised cords and spines. Shell pale-brown ochre, lighter dorsally on the cords and spines, darker brown on the open inner surface of the cords and on the varical margins; aperture and peristome translu- cent whitish. Color somewhat variable among the 10 specimens examined.

Measurements: Largest specimen examined $26.6 \mathrm{~mm}$ in length, width (excluding spines) 9.5 $\mathrm{mm}$; smallest specimen (lacking mature siphonal canal) $18 \mathrm{~mm}$ in length, width (excluding spines) $7.6 \mathrm{~mm}$, Bibbey collection.

Type locality: Off Cebu Island, Philippines.

Type depository: Personal collection of Dr. Tokio Shikama, Yokohama, Japan.

Material examined: Figured specimen SDMNH no. 72627 (figures 9, 10) and 1 other specimen, Bohol Island, Philippines, Leo Kempczenski collection; 3 specimens from off Punta Engaño, Mactan Island, Philippines Islands, Janowsky collection; 1 specimen, Mactan Channel, Philippines, in tangle-trawl, Bibbey collection; 1 specimen AMNH no. 183818, from Samar Island, Philippines, ex Bibbey collection; 2 specimens, Panglao, Bohol Island, Philippines, in trap, 1977-1978, Deynzer collection.

Remarks: This distinctive western Pacific species (Shikama, 1977, p. 15, pl. 2, figs. 10a, 10b) is characterized by the relatively small size of the body whorl, the slightly extended spire, the lengthy spines, and prominent webbing (figures 9, 10). It was compared by Shikama (1977, p. 15) to several unrelated long-spined species: Chicoreus damicornis (Hedley, 1903), C. axicornis (Lamarck, 1822), and Murex longicornis Dunker, 1864.

\section{SUBFAmILY Typhinae}

Genus Siphonochelus Jousseame, 1880

Type species: Typhis avenatus [sic] Hinds, 1844 (=T. arcuatus Hinds, 1843), by original designation.

\section{Siphonochelus radwini $n$. sp.}

Figs. 20, 21

Description: Shell small for genus, attaining 5 $\mathrm{mm}$ (holotype immature, lacking perhaps one body whorl), fusiform; spire acute, of $1^{1 / 4}$ bulbous nuclear whorls, followed by 3 weakly angulate postnuclear whorls; suture impressed. Body whorl large, fusoid; aperture small, ovate with an entire and erect peristome. Anal sulcus apparently lacking, but with a moderately long anal tube, arising at the rounded, poorly defined margin of shoulder 


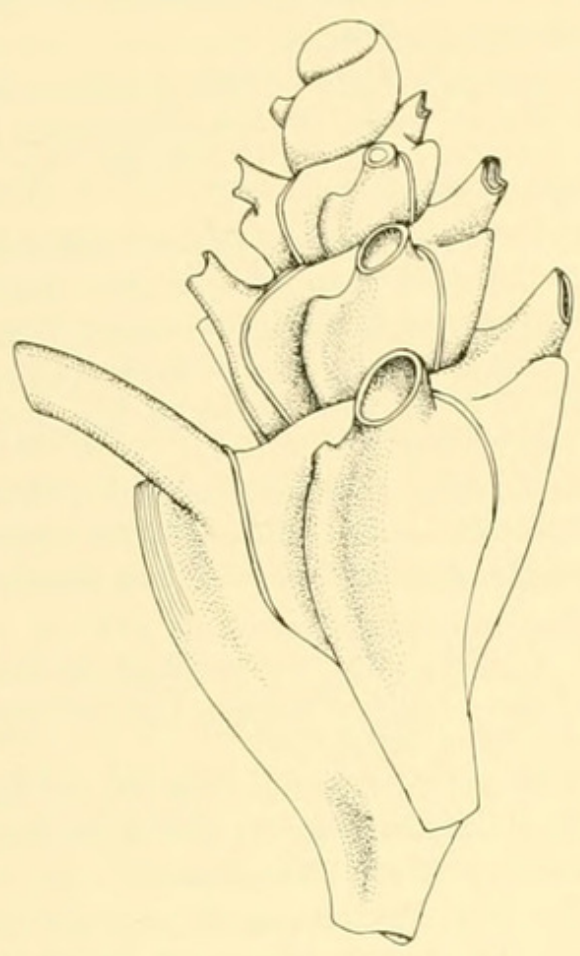

20

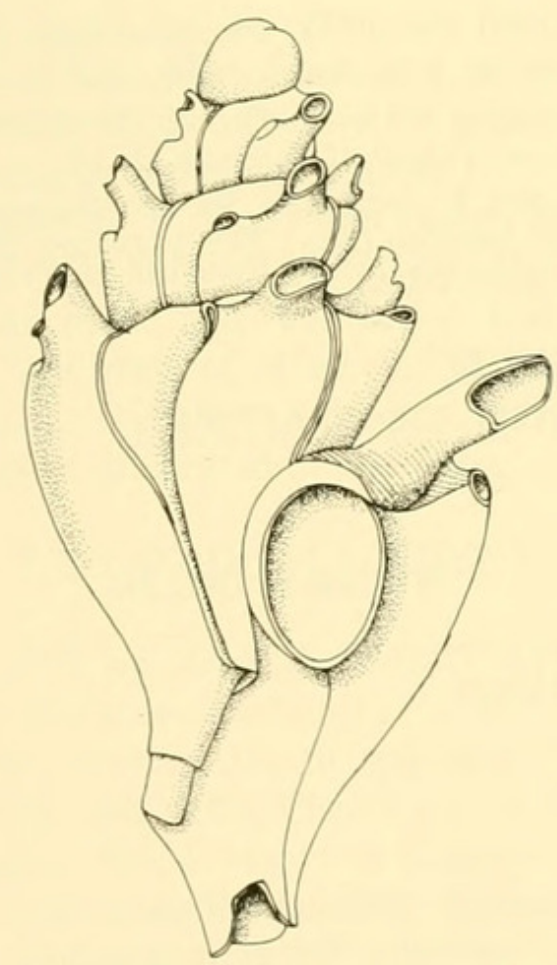

21

FIGS. 20 and 21, Siphonochelus radwini n. sp., holotype. NMNH 323198 (drawings by Anthony D'Attilio); greatly enlarged (natural size $=5.0 \mathrm{~mm}$. in length). in each varical interspace, and more closely placed to the earlier of the two varices. Proximal portion of each tube on the body swollen and axially depressed on the left side below the shoulder margin. A minor swelling produced on the leading side of each tube, terminating as a fold at the margin of the shoulder. Distal portion of tubes generally short, slanted, and irregular in crosssection. Last tube largest, weakly bent to the right, and the only one remaining open. Body whorl with 4 varices; each varical margin with a slight axial thickening corresponding to a former outer apertural lip. With increasing whorl size, position of each tube slightly ahead (in the direction of growth) of the corresponding tube on the preceeding whorl. Siphonal canal broad, moderately short, tapering, closed, bent to the right and dorsally recurved. Shell dull-white; aperture polished white.

Measurements: Holotype (figure 20, 21), length $5.0 \mathrm{~mm}$, width $2.5 \mathrm{~mm}$.

Type locality: Off Cabo Catoche, Yucatan, Mexico, dredged in 46 meters, USBF Sta. 2361.

Material studied: Holotype NMNH 323198.

Remarks: We have followed the genus-group concept of Radwin and D'Attilio (1976, pp. 198200) in assigning this new species to Siphonochelus, the first record of a living representative of this genus from the New World. Additional living species of Siphonochelus are recorded by these authors from the western Pacific and from off the Cape of Good Hope. It should be noted, however, that Radwin and D'Attilio (1976) rejected the previous assignment by several authors of western Atlantic species to Siphonochelus (e.g.: Keen, 1944; Gertman, 1969; and Bayer, 1971); see also Penna-Neme and Leme (1978) for their use of Siphonochelus for an eastern American species.

Although this taxon is based on a unique, apparently immature specimen, its distinctive morphology, together with its occurrence in the Western Hemisphere, has led us to describe it.

\section{LITERATURE CITED}

Bayer, F. M. 1971. Biological results of the University of Miami Deep-Sea Expedition 79. New and unusual mollusks collected by R/V John Elliot Pillsbury and R/V Gerda in the tropical western Atlantic. Bull. Mar. Sci. 21(1):111-236. 72 figs. 
Bivona-Bernardi, A. 1832. Caratteri di alcune specie de conchiglie, estratti come sopra. Effem Sci. Lett. Sicilia 2:16-24.

Blainville, H. M. D. de. 1829. Faune française ou histoire naturelle, générale, et particulière des animaux qui retrouve en France. Mollusques. Levraux, Paris 1-320, pls. $1-41$.

Clench, W. J., and I. Pérez Farfante. 1945. The genus Murex in the western Atlantic. Johnsonia 1(17):1-56, pls. 1-28.

Crosse, H. 1869. Diagnosis molluscorum novorum. Journ. de Conchyl. 17:408-410.

Deshayes, G. P. 1839. Nouvelles espéces de mollusques, provenant des côtes de la Californie, du Mexique, du Kamtschatka et de la Nouvelle Zélande, décrites par M. Deshayes. Rev. Zool. Soc. Cuvierierenne. 2:356-61.

Dunker, W. 1864. Fünf neue Mollusken. Malak. Blätt. 11:99-102.

Gertman, R. 1969. Cenozoic Typhinae (Mollusca: Gastropoda) of the western Atlantic region. Tulane Stud. Geol. and Paleont. 7(4):143-191, pls. 1-8.

Habe, T. 1961. Coloured illustrations of the shells of Japan [vol. 2]. Hoikusha, Osaka, 183 p., 66 pls.

Habe, T., and S. Kosuge. 1971. Pacific Shell News, Tokyo, Japan. (3):7. (Published on October 30, 1971).

Hedley, C. 1903. Scientific results of the trawling expedition of H. M. C. S. Thetis off the coast of New South Wales in Feb. and Mar., 1898, pt. 6. Mem. Australian Mus. 4(1):326-402, pls. 36-38, figs. 61-113.

Hinds, R. B. 1843. On new species of shells collected by Sir Edward Belcher, C. B. Proc. Zool. Soc. London, for 1843, 11:17-19 (July , 1843).

1844. The zoology of the voyage of H. M. S.

Sulphur. London, Mollusca, pt. 1, 1-24, pls. 1-7 (July, 1844).

Jousseaume, F. 1880. Division méthodique de la famille des Purpuridés. Le Naturaliste, 42:335-336.

Keen, A. M. 1944. Catalogue and revision of the gastropod subfamily Typhinae. Jour. Paleont. 18(1):50-72, 20 figs.
Lamarck, J. B. P. A. 1822. Histoire naturelle des animaux sans vertèbres. Paris, 7, 232 pp.

Melvill, J. C. and R. Standen. 1899. Report on the marine Mollusca obtained during the first expedition of Prof. A. C. Haddon to the Torres Straits in 1888-1889. Jour. Linn. Soc. London, 27:150-206, pls. 1, 2.

1903. Descriptions of 68 new Gastropoda from the Persian Gulf, Gulf of Cman and N. Arabian Sea dredged by Mr. F. W. Townsend of the Indo-European Telegraph Svc., 1901-1903. Ann. Mag. Nat. Hist. 12:289-324, pls. 20-23.

Monterosato, T. A. di. 1890. Conchiglie della profundita del mare di Palermo. Nat. Sicil. 9:140, 151, 157-66, 181-91.

Penna-Neme, L., and J. L. Moreira Leme. 1978. Novas espécies e novas ocorrências de gastropódos marinhos na costa Brasileira. Pap. Avulsos Zool., São Paulo 31(18):283-297, 33 figs.

Ponder, W. F. 1972, Notes on some Australian genera and species of the family Muricidae (Neogastropoda). Jour. Malac. Soc. Austral. 2(3):215-248.

Radwin, G. E., and A. D'Attilio. 1976. Murex Shells of the World, an illustrated guide to the Muricidae. Stanford Univ. Press, 284 p., 32 pls., 198 text figs.

Shikama, T. 1977. Descriptions of new and noteworthy Gastropoda from western Pacific and Indian Oceans. Sci. Reports, Yokohoma Natl. Univ., sect. 2, Biol. and Geol. Sci., no. 24:9-23, pls. 1-5, 2 figs.

Sowerby, G. B, II. 1834. The conchological illustrations, Murex. London, pls. 58-67.

1841. Ibid., pls. 187-189, and catalogue, p. 1-9.

Vokes, Emily H. 1975. Cenozoic Muricidae of the western Atlantic region. Pt. 6, Aspella and Dermomurex. Tulane Stud. Geol. and Paleont. 11(3):121-162, pls. 1-7.

Wanner, J. and E. Hahn. 1935. Miocäne Mollusken aus der Landschafe Rembang (Java). Zeitsch. Deutsch. Geol. Gesell., Berlin 87(4):222-273, pls. 17-21.

\title{
SCAPHELLA CONTOYENSIS, A NEW VOLUTID (GASTROPODA) FROM EAST MEXICO
}

William K. Emerson

\author{
and \\ Department of Invertebrates \\ American Museum of Natural History \\ New York, N. Y. 10024
}

\section{ABSTRACT}

\begin{abstract}
Scaphella contoyensis, a new species from the Yucatan Channel, Mexico, is described and compared with related volutid species of the New World subfamily Scaphellinae.
\end{abstract}

During the past decade, several examples of a large, thin-shelled volute have been obtained by shrimpers in depths ranging from about 70 to 180 meters in the Yucatan Channel, mostly in the vicinity of Contoy Light, off Cabo Catoche, Yucatan, Mexico. These specimens are somewhat 


\section{$2 \mathrm{BHL}$ Biodiversity Heritage Library}

1979. "Six new living species of muricacean gastropods." The Nautilus 93, 1-10. https://doi.org/10.5962/bhl.part.20324.

View This Item Online: https://www.biodiversitylibrary.org/item/34226

DOI: https://doi.org/10.5962/bhl.part.20324

Permalink: https://www.biodiversitylibrary.org/partpdf/20324

\section{Holding Institution}

MBLWHOI Library

\section{Sponsored by}

MBLWHOI Library

\section{Copyright \& Reuse}

Copyright Status: In copyright. Digitized with the permission of the rights holder.

Rights Holder: Bailey-Matthews National Shell Museum

License: http://creativecommons.org/licenses/by-nc-sa/3.0/

Rights: https://biodiversitylibrary.org/permissions

This document was created from content at the Biodiversity Heritage Library, the world's largest open access digital library for biodiversity literature and archives. Visit BHL at https://www.biodiversitylibrary.org. 